
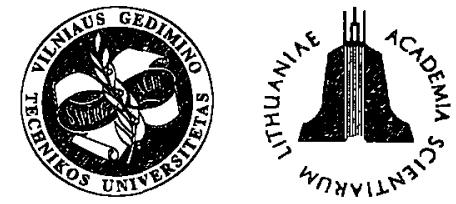

ISSN 1648-4142 TRANSPORT

http:/www.vtu.lt/english/editions

TRANSPORT - 2003, Vol XVIII, No 4, 174-18I

\title{
CONSISTENTS OF CAR'S PARKING IN LITHUANIAN TOWNS*
}

\author{
Marija Burinskienè, Gražvydas Paliulis \\ Dept of Urban Engineering, Vilnius Gediminas Technical University, \\ Sauletekio al.11,LT-2040Vilnius, Lithuania.E-mail: msk@ap.vtu.lt
}

Received 200306 23; accepted 20030630

\begin{abstract}
Large towns of Lithuania should especially focus on the solution of the parked cars; and modern technologies should be employed for that. The research methods have been substantiated and the recommendations for the technical regulations of the short-term and long-term car parking near different objects of attraction have been worked out on the basis of selective natural research, which is significant when issuing technical specifications to investors on the way the surroundings of the objects being built should be arranged and on what rearrangement of the urban streets is necessary. With a high level of motorization, the organization of the car parking process is a complicated problem of urban planning. The accumulated experience and the carried out analysis show that car parking problems can be positively solved even with a high level of motorization by: making use of the urban area as reasonably as possible so that the spaces could take the greatest possible number of cars; limiting the duration of parking so that the greater number of cars could use the same parking space; promoting car sharing; differentiating the entrance possibilities for different vehicles with regard of time, space and fee size. Solutions related to the determination of the parking space should be achieved in the context of the strategy of total urban development, area and traffic planning, traffic safety improvement and preservation of unique environment.
\end{abstract}

Keywords: parked cars, car parking, motorization level, transport system.

\section{Introduction}

The increasing number of population and the level of motorization cause the problem of parking the solution of which is much more complicated than that of other problems of traffic organisation. Each car used in the town should have at least two parking places: near the living place, and near the working place. And each of them needs 25 square meters of the land surface.

The most urgent problem of parking is encountered in the downtown as it is really complicated to find the space for short-term parking or at least for a short stopping there. The analysis of the parking research development has revealed that at the existing level of motorisation when 100 vehicles fall to 1000 inhabitants there is a shortage of the space for parking. First of all, there is the lack of the parking space on the carriageway near the sidewalk; then all the space in the parking facilities is also occupied. The problems become even more urgent when parking is forbidden on the carriageway in order to improve the capacity of the downtown streets.

Major contribution to the research of parking and solution of the related problems has been made by the scientists of USA, Germany, Great Britain, France, Swe-

\footnotetext{
* Discussion of results of programme "Transport: technologies, economic, environment, health"
}

den and other countries of Western Europe: Sill, O. [1], Smith, W. [2], Shoup, D. C. [3], Wilson R. W [4], Arentze, T. [5], Brown, B. [6], Safdie, E. [7], Meyer, R. [8]. In 1980-1990 the Polish scientists Dumnicki J. [9], conducted researches on the characteristics and regularities of car parking in the downtowns of Warsaw, Cracow, Poznan, Lodze and determined the policy of the organisation of parking places and forecast the number of parking places necessary in the downtowns.

In 1970 the first research on the parking places was carried out in Ohio, USA using the aero-photos; it proved the cost-efficiency ( $72 \%$ reduction in the labour costs), expedition ( $85 \%$ faster) and accuracy of this method, compared with the usual visual research [10].

The complex research on the parking in USA towns with the population approximating to 1 million was carried out in 1946-1954. At that time the motorisation level was totalling to $250-300$ vehicles/ 1000 inhabitants.

Basing on the data of the research conducted in Copenhagen, the Danish scientists state that to meet the needs for parking in the downtowns of the average size towns the number of the parking places should amount to $16-18 \%$ of the total number of the cars registered.

Valuable contribution has been made by German scientists D. Sill, G. Müller, A. Demelmayer, E. Schröder, etc. who carried out researches on the parking problems and their solutions in Hamburg, Köln, Frankfurt, 
Diuseldorf, Munich. The experience of these towns in the establishment of multi-storey garages in the downtown may be successfully used in the solution of transport problems in the big towns of Lithuania [11-13].

Nowadays, in Lithuania designing and construction of new buildings is not allowed in the downtown unless parking facilities of proper capacity are planned.

Coming to the downtown by car is rather complicated as there hardly is any free parking space on the working hours. Recently, the first special parking facilities taking several hundreds of vehicles have been installed in the downtown of Vilnius: parking facilities under Gediminas avenue take 260 vehicles, a multi-storey parking garage on Tilto street takes 180 vehicles, the underground parking facilities under the Business Centre on Jogailos street, etc. However, these facilities do not solve the problem of parking and only improve the parking conditions for a small group of people.

\section{Parking Research Methodology}

To have a clear understanding of the parking problem and to be able to manage it to the right directions as well as to maximally satisfy the parking needs in towns, it is necessary to undertake complex and well organised research and studies bases on such research.

Today the following is necessary in order to solve the parking issues:

- carrying out the research on the parking conditions in downtowns, old towns, multi-storey residential areas, and at the approaches of big trade centres;

- determination of the need for the parking space at different objects taking into consideration the existing level of motorization and with the perspective of 15 years;

- working out the solutions for the parking issues in the areas of the greatest attraction.

Recently, the authors of this paper have carried out the research on the parking space in Vilnius, Siauliai, Alytus, etc. The analysis of the research on parking enabled:

- the inventory of all parking facilities in downtowns and major residential areas;

- the determination of the maximum number of the parking facilities;

- the calculation of the main characteristics of the parking facilities: their use, duration of parking, dynamics of filling in the course of the day, size of fees, etc.

The information on the characteristics of the vehicles parked in the parking facilities, on the carriageway, in open yards, in garages was collected visually and with the help of digital camera. The research data and polling of drivers were used as the base for the analysis of the factors influencing the parking process: the source (sub- urb, urban transport area, etc.), the data on parking facilities, the destination (work, recreation, trade), the duration of parking, the type of parking (undergrounds parking facilities, the carriageway, the yard, a special structure for parking, garages), the duration of the walking trip (from the vehicle parked to the destination of the travel), the size of the parking fee.

The analysis of the above mentioned characteristics has enabled the division of the downtown into zones (setting the zones of the biggest lack of the parking space), the determination of the purpose of those who use the car to come to the downtown, the calculation of the parking duration depending on the purpose of the travel, the determination of the loading of the major parking spaces depending on the time spent in the downtown. All this information is indispensable for the installation of a rational parking system in towns, especially downtowns and old towns.

The needed extent of the parking space is mostly influenced by:

- the number of inhabitants of the town;

- the mobility of inhabitants, especially the number of trips to the downtown falling to an average person (per day, per year);

- the size of the downtown and its attractiveness;

- the attraction of the downtown at different hours of the day;

- the number, size and location of administrative, trade, and entertainment institutions in the downtown;

- the share of the travel to the downtown falling to the car;

- the level of the public transport services in the downtown.

\section{Analysis of the Main Features and Determination of Regularities}

In March 2002, the research was carried out in the old town of Vilnius in order to find out the nature of the destination objects and the number of visitors in them having the greatest impact on the vehicle concentration on the streets of the old town of Vilnius as well as to find out their inter-dependence.

The following streets were selected for the research: Vokieciu, Traku, Domininkonu, Sventaragio, T. Vrublevskio, Zygimantu, Barboros Radvilaites, Maironio, Liejyklos, L. Stuokos-Guceviciaus, Odminiu, and Totoriu. The streets were divided into $100 \mathrm{~m}$ long sections; the number of stores, administration institutions and cafés (restaurants, hotels) and the number in cars parked on those sections was found out.

The research results were processed using Statgraphics 2.1, which enabled the determination of the dependence between the cars parked and stores, administration institutions and cafés located there. 
The correlation analysis measured the extend of the statistic relation $y=f\left(x_{i}\right)$ and selected the factors having the greatest impact $y$ in the dependence $y=f\left(x_{1}, x_{2}\right.$, $\left.\ldots \mathrm{x}_{\mathrm{m}}, \ldots\right)$.

The correlation factor $r$ in the data analysis shows the intensity of the dependence between the variables in question.

The following is used in the data analysis:

AutSk is the number of the parked cars;

Kav is the number of cafés (restaurants, hotels);

Pard is the number of stores;

Adm is the number of administration institutions;

Lkav is the number of visitors in cafés (restaurants, hotels);

Lpard is the number of visitors of stores;

Ladm is the number of visitors of administration institutions.

Weak linear dependence when $0,2 \leq \mathrm{r}<0,4$;

Substantial linear dependence when $0,4 \leq r<0,7$;

Strong linear dependence when $r \geq 0,7$.

The obtained linear dependence has proved the fact that the number of the parked cars mostly depends on the number of administration institutions (the correlation factor in the data analysis is $r=0,31$ ).

$$
\text { Adm }=1,66422+0,0304704 \times \text { AutSt. }
$$

The research has revealed that the highest number of the cars parked within the $100 \mathrm{~m}$ long sections is seen at the administration institutions.

The stores that are in abundance in the old town attract a lower number of cars if compared with administration institutions (the correlation factor is $r=0,27$ ).

Pard $=1,02862+0,0574701 \times$ AutSk.

Cafés attracts even a lower number of cars $(\mathrm{r}=0,24)$.

$K a v=0,485725+0,0142119 \times$ AutSk.
The analysis of the number of visitors and the parked cars has resulted in a significantly higher inter-dependence of the variables as the number of visitors in the institutions is more define, i.e. it is a more specific factor predetermining the number of the parked cars than the number of institutions.

In this case the substantial linear dependence between the number of the parked cars and the number of visitors at the administration institutions is obtained (the correlation factor $r=0,54$ ).

$$
\text { AutSk }=11,0435+0,0744521 \times L a d m .
$$

The relation of the parked cars and the number of store visitors is slightly lower (the correlation factor $r=0,33$ ).

$$
\text { AutSk }=15,6684+0,0245708 \times \text { Lpard } .
$$

The linear relation of the parked cars and the number of café visitors is weak (the correlation factor $\mathrm{r}=$ 0,21 ).

$$
\text { AutSk }=16,4067+0,134494 \times \text { Lkav. }
$$

The weakest linear dependence between the parked cars and café visitors may be explained by the fact that the research was carried out in the day-time from midday till $2 \mathrm{pm}$, and the greatest number of café, restaurant and club visitors is seen after $5 \mathrm{pm}$.

The number of the cars parked in the streets of the old town of Vilnius is given in Table 1 where the research data of 2002 is compared with that of 1989,1997 , 2000 (table 1).

During the last two years $(2000-2002)$ the number of the cars parked in the old town of Vilnius boosted on Barboros Radvilaites and Vokieciu streets (1.6 times), the lowest growth was seen on Maironio and Odminiu streets $(0,7$ times). The variation of the number during the day was determined basing on the research of the cars parked in different parts of Vilnius. The number of cars parked in the downtown 11 am to $8 \mathrm{pm}$ accounts for

Table 1. The dynamics of the number of the parked cars on the streets of the old town of Vilnius

\begin{tabular}{|l|c|c|c|c|c|c|c|}
\hline Street & 1989 & 1997 & 2000 & 2002 & $\begin{array}{c}1989-1997 \\
\text { difference (times) }\end{array}$ & $\begin{array}{c}1997-2000 \\
\text { difference (times) }\end{array}$ & $\begin{array}{c}\text { 2000-2002 } \\
\text { difference (times) }\end{array}$ \\
\hline B. Radvilaites & 27 & 80 & 57 & 90 & 3,0 & 0,7 & 1,6 \\
Domininkonu & 46 & 16 & 16 & 19 & 0,3 & 1,0 & 1,2 \\
Maironio & 37 & 37 & 59 & 44 & 1,0 & 1,6 & 0,7 \\
Sventaragio & 60 & 79 & 78 & 100 & 1,3 & 1,0 & 1,3 \\
Traku & 17 & 22 & 33 & 38 & 1,3 & 1,5 & 1,2 \\
Vokieciu & 78 & 80 & 92 & 147 & 1,0 & 1,2 & 0,6 \\
Liejyklos & 19 & 29 & 27 & 25 & 1,5 & 0,9 & \\
L. Stuokos- & & & & & & & 1,1 \\
Guceviciaus & 8 & 21 & 32 & 34 & 2,6 & 3,5 & 0,7 \\
Odminiu & 16 & 12 & 36 & 26 & 0,8 & 3,0 & 1,2 \\
Totoriu & 22 & 77 & 151 & 182 & 3,5 & & 2,0 \\
\hline
\end{tabular}


85 percent of all the cars parked, in the Old Town 80 percent is reached at $1 \mathrm{pm}$ and is seen till $9 \mathrm{pm}$, while in the residential areas the maximum number of cars is parked $7 \mathrm{pm}$ to $8 \mathrm{am}$. These differences in the car parking enables to use of the same parking facilities at different time of the day. This is another reason for the integrated development of the town (Fig 1).

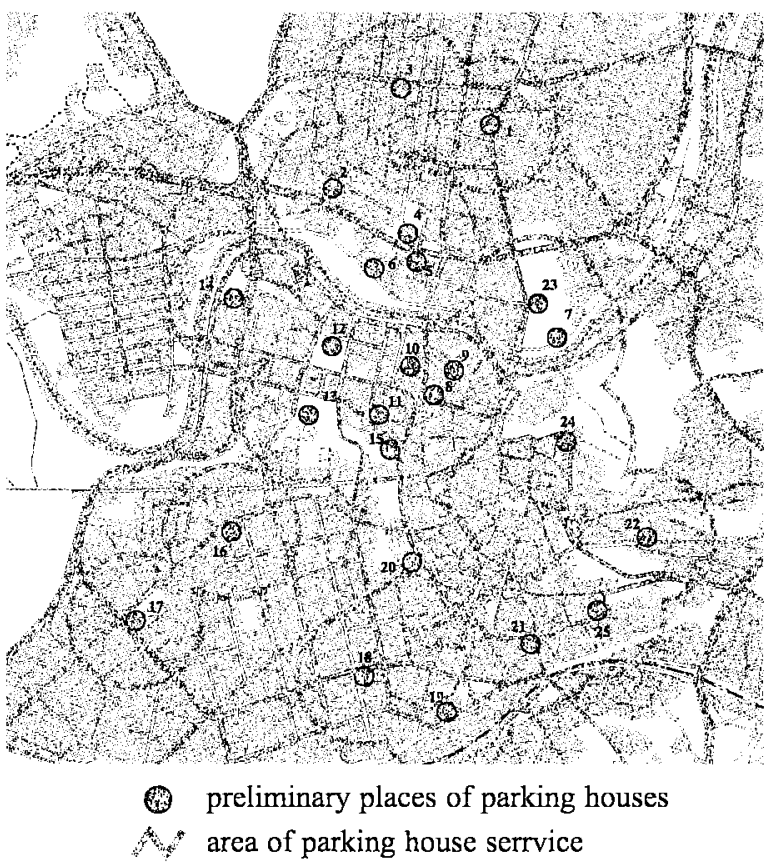

Fig 1. Location scheme of multistory parking houses in a central part of Vilnius territory

Speaking of the paid parking, a different situation is seen in Siauliai, where the existing system is not perfect, lacks soundness and control. The need for the car parking there is not very extensive so that people would pay for the car parking as it is not a problem to find space for parking within the distance of 50-100 meters. Besides, many yards do not have barriers or gates preventing the entrance of cars.

In November 2002, a visual survey of the parking facilities was carried out and revealed the real filling of and the real need for the parking facilities. It should be noted that there still is a considerable number of the public parking facilities.

The results of the survey carried out in Siauliai are presented in Table 2.

Following the normative requirements valid for the parking, this area and its surroundings (up to 150 meters) should have approximately 2100 places for parking. However, the survey has revealed that the existing number of the parking facilities is close to the needed one, as the total filling goes up to 70-85 percent.

The survey carried out in Siauliai revealed that the existing number of the parking facilities satisfied the need for them.
Table 2. The filling of the parking facilities in different areas of Siauliai

\begin{tabular}{|l|c|c|}
\hline The function of the area & $\begin{array}{c}\text { The filling } \\
\text { level of } \\
\text { facilities, \% }\end{array}$ & $\begin{array}{c}\text { Fully filled } \\
\text { and overfilled } \\
\text { facilities, \% }\end{array}$ \\
\hline Multi-storey residential area & 56,8 & 5,0 \\
Low-rise residential area & 67,7 & 0 \\
Northern industrial area & 49,0 & 20,0 \\
Southern industrial area & 60,9 & 27,0 \\
Southern poly-functional & 40,0 & 0 \\
centre & 84,0 & 65,0 \\
Downtown & 40,0 & 0 \\
Recreational area & & \\
\hline
\end{tabular}

A similar research carried out in Alytus enabled the measurement of the parking conditions in different parts of the town. The research was carried out basing on the polling of citizens (Table 3 ).

During the poll, it was determined that the major part of Alytus inhabitants found the parking conditions in the downtown acceptable, and those near the working place seemed good to them. The most complaints with regards to the parking conditions fell to the districts of Dainavos, Putinu and the new downtown; the praises fell to the $1^{\text {st }}$ District of Alytus, the downtown and its approaches.

The way the inhabitants park their cars at night depends on the type of the housing. In multi-storey resi-

Table 3. Evaluation of the parking conditions in Alytus

\begin{tabular}{|c|c|c|c|c|}
\hline Location & $\mathrm{Bad}$ & Satisfactory & Good & No respond \\
\hline Downtown & 31,4 & 46,9 & 7,3 & 14,4 \\
\hline $\begin{array}{l}\text { Near the place } \\
\text { of dwelling }\end{array}$ & 32,0 & 38,6 & 19,7 & 10,7 \\
\hline $\begin{array}{l}\text { Near the place } \\
\text { of work }\end{array}$ & 11,7 & 39,8 & 27,4 & 21,1 \\
\hline
\end{tabular}

Table 4. The car parking ways in Alytus

\begin{tabular}{|l|c|c|c|c|}
\hline District & $\begin{array}{c}\text { In the } \\
\text { yard }\end{array}$ & $\begin{array}{c}\text { In } \\
\text { a metal } \\
\text { garage }\end{array}$ & $\begin{array}{c}\text { In } \\
\text { a brick } \\
\text { garage }\end{array}$ & $\begin{array}{c}\text { In protected } \\
\text { parking } \\
\text { facilities }\end{array}$ \\
\hline The downtown & 41,0 & 6,7 & 48,7 & 3,7 \\
Dainava & 55,5 & 6.6 & 32.6 & 5,0 \\
Alutis I & 20,0 & 2,6 & 73,8 & 3,7 \\
Likiskeliai & 64,7 & 4,3 & 26,0 & 5,0 \\
Vizgirdis & 54,7 & 5,7 & 34,7 & 5,0 \\
Astra & 46,2 & 11,6 & 38,4 & 3,8 \\
Kurortas & 20,0 & 6,7 & 73,3 & 0 \\
Naujasis centras & & & & \\
(the New & & & 30,2 & 25,2 \\
Downtown) & 38,4 & 6,2 & 30,2 \\
Putinai & 50,5 & 12,3 & 27,7 & 9,6 \\
\hline
\end{tabular}


dential areas cars are usually parked in the yard $(50,5$ $64,7 \%$ ), in low-rise residential areas they are usually parked in garages. In mixed area protected parking facilities are more popular and the number of cars parked in yards and in garages distributes more evenly (Table 4).

The duration of the car parking in the downtown is not long, thus the turnover of the parking places is rather good and no urgent restrictive measures (levy per place or per time) are necessary (Fig 2).

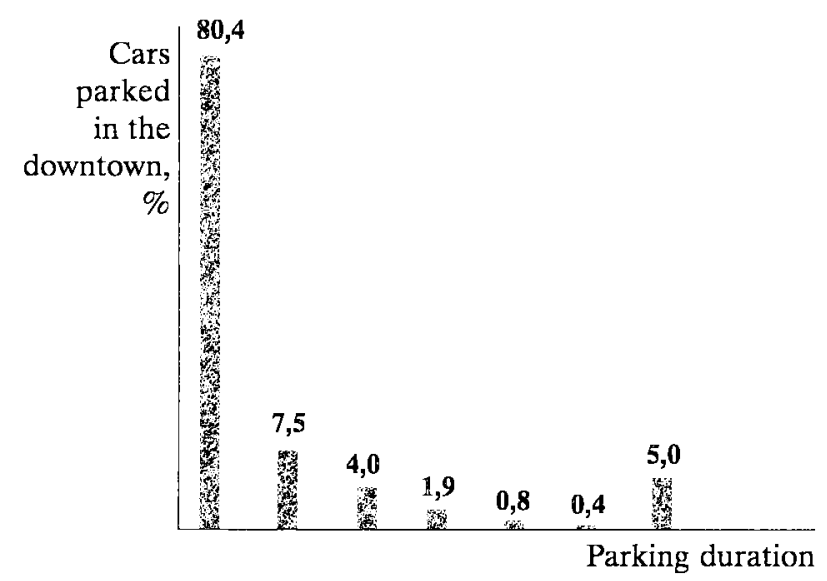

Fig 2. Parking duration in the downtown of Alytus (\%)

\section{Peculiarities of the Parking Near Big Trade Cen- tres (Supermarkets)}

With the growing national economy, the recent five years have seen the rise of very big trade centres which attract a lot of visitors.

These trade centres cover huge urban areas. The experience of the USA and Western Europe shows that most of their visitors come by cars.

A grooving level of motorisation in the country, the increasing mobility of people, and the attraction of the big trade centres demand extensive parking facilities close to them. In Vilnius, Kaunas and Klaipeda such trade centres are built close to the arterial streets and their influence on the traffic flows and organisation needs a thorough analysis. The big trading centres is a phenomenon quite new in Lithuania and the researches on their impact on the urban transport system have only started. The foreign experience evidences that this problem will become even more urgent in future. In 1968, there were 73 big supermarkets in the USA; in 1974 their number boosted to 249, while in 1999 it reached 714 [14]. Big supermarkets cause not only parking related problems but they also have impact on the transport system of that area (Table 5).

In April-May 2002, the Urban Construction Department of Vilnius Gediminas Technical University carried out the research on the transport close to the big supermarkets and trade centres.
Table 5. Filling of parking facilities located close to the supermarkets and other trade centres on Ukmerges street in Vilnius

\begin{tabular}{|l|l|c|c|c|c|}
\hline No & $\begin{array}{l}\text { Supermarket } \\
\text { or trade } \\
\text { centre }\end{array}$ & $\begin{array}{c}\text { The } \\
\text { existing } \\
\text { number } \\
\text { of parking } \\
\text { places }\end{array}$ & $\begin{array}{c}\text { The } \\
\text { average } \\
\text { filling } \\
\text { on working } \\
\text { hours }\end{array}$ & $\begin{array}{c}\text { The } \\
\text { filling } \\
\text { on the } \\
\text { rush } \\
\text { hours }\end{array}$ & $\begin{array}{c}\text { The } \\
\text { average } \\
\text { filling } \\
\text { on the } \\
\text { day-off }\end{array}$ \\
\hline 1. & Senukai & 346 & 240 & 286 & 267 \\
2. & IKI & 222 & 50 & 162 & 68 \\
3. & Statybu aleja & 128 & 32 & 49 & 42 \\
4. & Maxima & 360 & 108 & 311 & 242 \\
5. & Voke III & 52 & 11 & 17 & 31 \\
6. & Volvo centras & 55 & 12 & 32 & 34 \\
7. & Décor C & 50 & 18 & 28 & 35 \\
8. & Thomas Philips & 44 & 13 & 16 & 24 \\
9. & Nuost. Sureg. & & & & \\
10. & Centras & 70 & 34 & 42 & 27 \\
\hline
\end{tabular}

The transport research carried out near the trade centre Akropolis (Vilnius), which is the biggest one in Lithuania, revealed that it attracted the greatest flows of visitors. On working days the number of visitors on the average reaches 21160 , and on the days-off it reaches 35440 . The capacity of the parking facilities close to Akropolis is 2600 parking places and the research showed that it has the most intensive filling at $5-6 \mathrm{pm}$ on working days (1895 cars or $73 \%$ ), and the average filling of the hour on the working days is 648 cars $(25 \%)$, while the average filling on the days-off is 1539 cars $(60 \%)$. The analysis of the parking places close to the supermarket showed that it is one of those rare objects where free space for parking is available.

The analysis of the research on the way the people come to Akropolis revealed that $60-70 \%$ of visitors came by cars, $24-32 \%$ by the public transport, and only 6-8 \% came on foot from surrounding residential areas. This coincides with the similar research carried out in Poland and Germany. The transport flow dynamics showed that the greatest flows of visitors on the working days were at 4 to $8 \mathrm{pm}$. Another rise in the vehicle flows was at 9 to $10 \mathrm{pm}$.

The research showed that at the rush hours of the days-off the number of visitors was $57-72 \%$ bigger than that on the working day.

The capacity of the parking facilities depends on the duration of parking (rotation) and the filling. The filling with the cars of the visitors to the big supermarkets on the working days was 1,56 and on the days-off was 1,82 .

Big supermarkets will be built in future, too. And their impact on the transport system should be analysed in larger surrounding areas. 
The compiled research database will allow modelling and forecasting of the traffic near the big supermarkets as situation is very similar in Vilnius, Kaunas and Klaipeda. Common regularities of transport attraction and traffic are similar in Siauliai, Panevezys, Alytus. The transport system analysis will secure a rational choice of the place for new supermarkets having convenient approach and an optimal number of parking places, as well as it will minimize a negative impact on the total transport system.

\section{Comparison of Lithuanian and Foreign Parking Norms}

A limited street network in the downtowns and old towns of Lithuanian towns causes a lot of parking related problems. The number of parking places depends on the number of cars parked in that area by the people working, visiting or living there and the duration of parking.

The main parameters of the parking places are regulated by Technical Regulation on Construction STR 2.06.01:1999 [15]. Drafting the urban development projects encounter the problem of the perspective parking and the calculation of the necessary parking space. The regulation gives the guiding norms on parking near individual objects with the motorization level going up to 400 vehicles / 1000 inhabitants. However, in the urban areas that had developed historically and that are densely built it is impossible to install the parking facilities complying with the normative regulations. The lack of parking space in such area must be compensated by installing parking facilities at the approaches to the old town.

According to the STR, the number of the parking places should be specified after taking into consideration the following:

1) the existing and the forecast number of the cars of permanent residents and enterprises and the intensity of their usage;

2) the number of the cars of daily, periodical and episodic visitors and the intensity of their usage;

3 ) the duration of parking;

4) the need for the car parking near the dwelling houses, places of work, recreation, services, etc. with the $\mathrm{P}+\mathrm{R}$ (Park-and-Ride) or similar system.

The number of parking places for a specific town given in the regulations should be specified taking into consideration: the existing and the forecast number of cars; the administrative status of the specific town; functional peculiarities, the situation in the national road system and other peculiarities, including the need to limit the number of parking places, the functional purpose of a specific town, its districts, zones, etc., the existing and the forecast number of the parking places (the need for investment, proper land plots, underground space, street permeability, priorities of the Public passenger communication and walking).

Lithuanian parking norms (STR) have been compared with those of Germany (DIN), Switzerland (SN), Russia (СНиП), Estonia (RTL) [16-19].

The norms of different countries use different measuring units. For example, in Estonia the number of the parking places is given only in $\mathrm{m}^{2}$, in other countries the number is given per apartment, room, sitting place, bed, etc. The latter variant is more accurate in designing the parking places. The parking places near the dwelling houses are mostly dealt with in DIN and SN; those near stores are dealt with in $\mathrm{SN}$ and $\mathrm{CHиП;} \mathrm{those} \mathrm{at} \mathrm{the} \mathrm{places}$ of public gathering are dealt with in DIN and CHиП; those near industrial enterprises are dealt with in DIN. Lithuanian parking norms are close to the German ones (DIN) as the regulation on technical specifications has been worked out basing on the. The limits of norms depend on the needs of the residents, building density, working place concentration, motorization level, etc. of each country. In 1997, speaking of the five countries, the highest motorisation level was seen in Germany and Switzerland (505 and 550 per 1000 inhabitants, accordingly) [20]. So the greatest requirements with regards to the parking places are imposed in these countries. In 1997 in Lithuania the motorization level was 233 vehicles / 1000 inhabitants, in Estonia 180 vehicles / 1000 inhabitants, in Russia 135 vehicles / 1000 inhabitants.

Taking into consideration a rapidly growing motorisation level, at the dwelling houses there should be at least 1 ( 2 in perspective) parking place per one apartment and not 0,8 as stated in STR. The German DIN gives $1-1,5$ place for that. Swiss SN givrs one parking place per $80-100 \mathrm{~m}^{2}$, i.e. approximately 2 places per 3 apartments or 1,5 place per one apartment. Russian СНиП gives $30-40$ places per 1000 inhabitants.

Recently, there is a trend of building large supermarkets. They should have 1 parking place per each 10$20 \mathrm{~m}^{2}$ of the trade hall area, and not 1 per each $20 \mathrm{~m}^{2}$ as it is foreseen in STR. By its motorisation level, Lithuania does not lag behind developed foreign countries, what means that the growth trends of in the number of cars will sustain for a long time and planning the parking facilities near supermarkets it is necessary to observe the norms of other countries, for example Germany where 1 parking place is given per each $10-20 \mathrm{~m}^{2}$ of the trade hall area.

Cinema has become rather popular in Lithuanian towns, thus it is expedient to install 1 parking place per each 8-10 (and not 12) sitting places. Germans give 1 parking place per 5-10 sitting places. Russian norms foresee $10-15$ places per 100 places or visitors. That would be approximately $1-2$ car parking places per 10 sitting places.

With the growth of the motorisation level, it is ex- 
Table 6. The numbers of the parking places foreseen in the parking norms of Lithuania and other countries and the changes proposed in STR

\begin{tabular}{|c|c|c|c|c|c|c|}
\hline \multirow[t]{2}{*}{ Object } & \multicolumn{5}{|c|}{$\begin{array}{l}\text { The number of parking places established in the norms of Lithuania, } \\
\text { Germany, Switzerland, Russia and Estonia }\end{array}$} & \multirow[t]{2}{*}{$\begin{array}{l}\text { Proposed } \\
\text { in STR }\end{array}$} \\
\hline & STR & DIN & SN & СНиП & RTL & \\
\hline $\begin{array}{l}\text { Multi-storey } \\
\text { houses }\end{array}$ & $\begin{array}{l}0,8 \text { per each } \\
\text { apartment }\end{array}$ & $1-1,5$ & $\begin{array}{l}1 \text { per each } \\
80-100 \mathrm{~m}^{2}\end{array}$ & $\begin{array}{l}30-40 \text { per } \\
1000\end{array}$ & $\begin{array}{l}0,3 \text { per each } \\
\text { apartment }\end{array}$ & $\begin{array}{l}1-2 \text { per each } \\
\text { apartment }\end{array}$ \\
\hline $\begin{array}{l}\text { Supermarkets, } \\
\text { trade centres }\end{array}$ & $\begin{array}{l}1 \text { per each } \\
20 \mathrm{~m}^{2} \text { of the } \\
\text { trading hall } \\
\text { area }\end{array}$ & $\begin{array}{c}1 \text { per each } \\
10-20 \mathrm{~m}^{2} \text { of the } \\
\text { trading hall } \\
\text { area }\end{array}$ & none & $\begin{array}{c}\text { inhabitants } \\
20-25 \text { per } \\
\text { each } 10-50 \\
\text { trading places }\end{array}$ & $\begin{array}{l}1 \text { per each } \\
180 \mathrm{~m}^{2} \text { of the } \\
\text { store }\end{array}$ & $\begin{array}{c}1 \text { per each } \\
10-20 \mathrm{~m}^{2} \text { of the } \\
\text { trading hall } \\
\text { area }\end{array}$ \\
\hline $\begin{array}{l}\text { Cinemas, } \\
\text { conference } \\
\text { halls }\end{array}$ & $\begin{array}{c}1 \text { per } 12 \text { sitting } \\
\text { places }\end{array}$ & $\begin{array}{c}1 \text { per } 5-10 \\
\text { sitting places }\end{array}$ & none & $\begin{array}{l}11-15 \text { per } 100 \\
\text { places or }\end{array}$ & 1 per $180 \mathrm{~m}^{2}$ & $\begin{array}{l}1 \text { per } 8-10 \\
\text { sitting places }\end{array}$ \\
\hline Universities & $\begin{array}{c}1 \text { per } 6 \\
\text { students, } 1 \text { per } \\
3 \text { employees }\end{array}$ & $\begin{array}{l}1 \text { per } 2-4 \\
\text { students }\end{array}$ & $\begin{array}{l}\text { The need for the } \\
\text { places is determi- } \\
\text { ned analysing the } \\
\text { transport planning }\end{array}$ & $\begin{array}{c}\text { visitors } \\
10-20 \text { per } 100 \\
\text { professors }\end{array}$ & 1 per $500 \mathrm{~m}^{2}$ & $\begin{array}{l}1 \text { per } 3-4 \\
\text { students }\end{array}$ \\
\hline
\end{tabular}

pedient to foresee 1 parking place per 3-4 9and not 60 students at the universities of Lithuania. The German norms give 1 parking place per 2-4 students, Russian norms give 10 to 20 parking place per 100 professors.

The comparison of Lithuanian norms on parking with German, Swiss, Russian and Estonian ones resulted in the selection of the objects that should have a different number of the parking places than that established in STR (Table 6).

\section{Development of Parking Places}

According to STR, the number of the parking places in the central area of Vilnius should reach $68 \%$ of the total amount of the cars available in town. The approach distance to a temporary parking place should not exceed $400 \mathrm{~m}$. The number of the parking places in the downtown of Vilnius (taking 6-8 \%) at present should be 912 thousand places, in future it should reach 12-17 thousand places. The realisation of this task is hardly possible. To secure such number of places it is indispensable to build multi-storey parking facilities which then call for designing, approving and implementing the schemes of parking place distribution in the central part of the town and determination of the locations for multistorey underground garages.

For the introduction of $\mathrm{P}+\mathrm{R}$ (park and ride) system, it is necessary to form the system of parking facilities near large junctions of the public transport.

For $\mathrm{P}+\mathrm{R}$ system to be introduced in Vilnius, the town has to implement the plans for the improvement of the main communication system provided in the strategic plan of Vilnius. The crucial thing is to introduce a new high-speed tram as only then the permeability of the public transport will improve and one of the main criteria of successful functioning of $\mathrm{P}+\mathrm{R}$ system will be realised.

The main car parking policy principle is the intercompatibility of territorial planning and traffic. The parking system should have connection between the territory and the transport system. The parking system should be clear and based on the principles of harmonious development, and its implementation should be timely and receive all the necessary financing. The principles of car parking should assist in achieving the set goals related to urban area use, transport, financial resources and environmental protection realising the town humanisation ideas.

\section{Conclusions}

1. The strategy of parking should have clear goals related to the following trends:

- the policy of the preservation of urban environment, cultural and historical urban values;

- urban development taking into consideration urban infrastructure development;

- business development policy;

- development and preservation of trade, recreation and cultural centres;

- security of the administrative function of the town: transport policy related to transport flow distribution on the street network, supply of parking places, traffic safety;

- financial benefit.

2. Solutions of car parking should be coordinated and integrated into the general process of the urban development planning taking into consideration the goals of car parking policy. The growing motorisation level will result in a greater need for the parking places; however, reservation of the areas in the central parts of the 
town for that is rather expensive, thus a common urban transport strategy integrated into the land use and securing the sustainability in time, foreseeing free transport areas and the priority of the public transport is needed.

3. Taking into consideration the EU standards of parking, it is necessary to secure strict observation of rules for the parking with regards to all groups of traffic participants and for the transport of the disabled. The securing these rules has the following main goals:

- prevention and training

- $\quad$ securing necessary parking places

- convenient approach

- $\quad$ securing supply of places

- reorganisation of the public transport

- installation of the underground parking facilities' network

- information system of parking facilities

- differentiated parking fee system

4. The improvement of the urban transport system needs a monitoring system, the implementation of which needs the analysis of the transport flows on streets and crossroads, passenger flows on the public transport, occupancy or the exiting parking facilities.

5. On the streets of the towns of Lithuania, within the recent 10 years the transport flows have increased 2.4 times. In Vilnius, the motorisation level annually increases 9-12\%, thus with each year it is more complicated to find free space for parking. The problems related to car parking in the downtown of Vilnius are predetermined not only by a growing level of motorisation, but also by a limited network of streets, i.e. the existing infrastructure and lack of it. In 2002, the total length of the street network was $924.6 \mathrm{~km}$ and recently there have been no signs of its expansion.

6. Lithuanian parking norms are close to the German ones (DIN). The greatest requirements with regard to the parking places are imposed in Germany and Switzerland. The norms of parking at some object groups set in STR should be changed taking into consideration the existing and the perspective motorisation level in Lithuania: the cars parked at supermarkets should be given 1 parking place per $10-20 \mathrm{~m}^{2}$ of the trade hall area; the cars parked at cinemas should be given 1 parking place per 8-10 sitting places (not 12); the cars parked at universities should be given 1 parking place per 3-4 students.

\section{References}

1. Still, Rolle des Automobils in stadten. Boston. World Traffic Engineering Conference, Vol 245, 1985.

2. Smith, W. Parking in the city center. New Hawen. Vol 172, 1988.
3. Shoup, D. C. An opportunity to reduce minimum parking requirements. Journal of the American Planning Association, Vol 61, 1995.

4. Wilson, R. W. Suburban parking requirements: a tacit policy for automobile use and sprawl. Journal of the American Planning Association, Vol 61, 1995.

5. Arentze, T.; Timmermans, H. Measuring impacts of condition variables in rule-based models of space- time choice behavior. Geographical Analysis, Vol 35, 2003.

6. Brown, B. B.; Cropper, V. L. New Urban and Standard Suburban Sub divisions. Journal of the American Planning Association, Vol 67, 2001.

7. Safdie, M. E.; Kohn,W. E. The City after the Automobile: An Architect's Vision. Westview Press, Vol 144, 1998.

8. Meyer, R. Essays in Transportation Economics and Policy. Brookings Institute, Vol 121, 1999.

9. Dumnicki, J.; Kreczmas, J.; Remisz, L. Parking in the city (Parkingi w miestach). Warszawa: WKL, Vol 181, 1989. (in Polisch).

10. Litman, T. Win-Win Transportation management strategies: Cooperation for economic, social and environmental benefits. Journal of Business Administration and Policy Analysis, Vol 58, 1999.

11. Cobb, C. The roads aren't free. Challenge, Vol 42, 1999.

12. Giuliano, G. Transportation demand management; Promise or panacea? Journal of the American Planning Association, Vol 58, 1992.

13. Bjorklun, E. C. Teaching About Personal Injury Law: Activities for the Classroom. Social Studies, Vol 86, 1995.

14. Pollard, O. A. Smart growth and sustainable transportation: can we get there from here? Fordham Urban Law Journal, Vol 29, 2002.

15. Transportation systems of towns and countrysides (Miestu, miesteliu ir kaimu susisiekimo sistemos). STR 2.06.01:1999. Vilnius, 1999. 47 p. (in Lithuanian).

16. Standard for street design Estonia (Tee projekteerinuse normid ja nouded). Tallin. 2000. 96 p. (in Estonian).

17. Deutsche Infrastrukture Normen. DBV. EAR. $1997.532 \mathrm{p}$

18. Vereinigung Schweizerischer streßen fachlente VSS Eingefragene Norm der Schweizerischen NormenVereinigung. Zürich. 131 p. 1993.

19. Development of cities. Building up and planning of urban and rural places in Russia (Градостроительство. Планировка и застройка городских и сельских поселений). Moscow. 2000. 56 p. (in Russian).

20. European Commission. EU Transport in Figures (Statistical pocket book). 1999. $125 \mathrm{p}$. 